\title{
THE EARLY COMPETITIVE ERA IN TELEPHONE COMMUNICATION, I893-1920
}

\author{
RichaRd Gabel*
}

I

\section{INTRODUCTION}

\section{A. The Conventional View of Competition and Regulation}

There is no general theory of public utility regulation. What often passes for theory is a reconstruction of historical events woven into a pattern of generalization to meet contemporary issues. Thus, while the thesis that "Regulation is the law's substitute for competition" is the legend on the wall of the Michigan Public Service Commission's hearing room, ${ }^{1}$ there is scant evidence that those who involse the slogan have examined the differential impact of market competition and regulated monopoly on price, market development, and innovation. While market competition provides consumers no perfect guarantee of price benefits or rapid technical and operating innovation, it creates a readier climate for such developments than does regulated monopoly. The available historical evidence indicates that, at least in the communications industry, regulation has served to stabilize price and earnings of the carriers, has inhibited innovation in rate structures, and has protected the carriers from the competitive inroads of private manufacturers and suppliers.

The possibility of introducing additional competition in the rendering of communications services has recently come to the fore. Private microwave suppliers have threatened the monopoly of the Bell System over supply of intercity toll services, ${ }^{2}$ and the use of the computer as a switching device has offered the possibility of substitution for established common carrier services. ${ }^{3}$

* Chief, Planning and Analysis Division, Office of Telecommunication, U.S. Department of Transportation. The views expressed do not necessarily reflect the opinions of the Department or any element thereof.

${ }^{1}$ AT\&T, Profit, Performance and Progress, A Study of Regulated and Nonregulated Industry FOR BeLl System Use 64 (I952).

${ }^{2}$ See Applications of Microwave Communications, Inc, Nos. I6509-19 (F.C.C., designated for hearing Feb. 2, 1966). Despite the opposition of AT\&'T and Western Union, this application was granted, FCC 69-870 (Aug. 13, x969).

${ }^{3}$ Regulatory and Policy Problems Presented by the Interdependence of Computer and Communication Services and Facilities, No. 16979 (Notice of Inquiry), 7 F.C.C.2d II, 18-19 (1966):

"From the common carriers' standpoint, regulation should extend to all entities offering like services or to none. It is urged that the ability to compete successfully depends on the flexibility required to meet the competition, and that the carriers would be deprived of this flexibility if they alone were restricted in their pricing practices and marketing efforts by the rigidities of a tariff schedule. Thus, we are confronted with determining under what circumstances data processing, computer information, and message switching services, or any particular combination thercofwhether engaged in by established common carriers or other entities-are or should be subject to the provisions of the Communications Act." 
These are just two of several developments in technology which could alter the structure of the communications industry.

Potential changes in market or regulatory structure almost invariably breed new explanations for existing conditions, or, as here, recrudescence of old ideology. Thus, in a dissent to the Report of the Presidential Task Force on Communications Policy, the Director of the Office of Telecommunications Management stated,

Experience going back some seventy years has demonstrated that competition in the provision of local telephone service was inherently inefficient and led to poorer quality service at higher cost. ${ }^{4}$

The history of the period of communications competition in the United States, roughly the years 1893 to 1920 , is apparently not too well known, and the view that the existence of competition in communications led to inefficiency, poorer quality, and higher cost in telephony is arrived at by a series of logical inferences which ignore the evidence that is favorable to competition. It will be the purpose of this paper to review this segment of domestic economic history and at least to question the contention raised in the preceding quotation.

\section{B. Survey of the Competitive Era}

The independent telephone industry began in 1893 with the expiration of the Bell System patents on the telephone handset. From its inception until about rgr 3 there was limited interconnection between the independent and the Bell exchanges. Refusal to interconnect was, of course, a tool employed in the competitive battle for domination of the industry. Interconnection refusal was not limited to the strictly duplicating situations, but was also extended to service areas where Bell had never chosen to provide telephone service. When competition took the form of overlapping exchanges of rival companies, ${ }^{5}$ the impact on plant requirements was apparent. A subscriber desiring telephone service with access to all users was required to obtain two separate telephone instruments; a separate subscriber loop had to be furnished from each telephone instrument to a central office, necessitating separate central office lines both served by switchboard operators. ${ }^{6}$ There clearly must have been some duplication of facilities and investment under this arrangement.

See also Irwin, The Computer Utility: Competition or Regulation?, 76 YALE L.J. I299 (1967); Irwin. Computers and Communications: The Economics of Interdependence, in this symposium, p. 360 ; Dunn, Policy Issues Presented by the Interdependence of Computer and Communications Service, in this symposium, p. 369 .

"President's Task Force on Communications Policy, Final Report app. A, at i (ig68) (dissent of General James O'Connell) [hereinafter cited as TASK FoncE REPORT].

'In 1907 , overlapping territory was estimated at $20 \%$, but this was only about one-third of all exchanges. G. Johnston, Some Comments on the I907 Annual Report of AT\&T (Int'l Independent Tel. Ass'n, Sept. Igo8).

- The duplication of subscriber directory services must have been a source of annoyance to business customers. 
However, the degree of "inefficiency" and "higher cost" has never been demonstrated, and perhaps it is not determinable.

Early Bell System telephone development took place at the business core of large urban communities. ${ }^{7}$ Since territorial extension by the competing independents was for the most part to contiguous rather than overlapping geographic areas, ${ }^{8}$ the provision of distribution plant must have been more often complementary than duplicative. For the small central offices in use at the time there were no significant differences in cost per line for, separate as against combined switching facilities, and, in the absence of interconnection, this could not have materially affected total investment.9 Dual services, in the absence of interconnection of the rival companies at the central offices, necessarily required dual telephone instruments, but the instrument and its associated wiring probably made up less than ten per cent of the average investment per station. ${ }^{10}$ Any rigorous examination of the effect of competition on communication costs would require knowledge of the capacity and rate of utilization of facilities prior to and subsequent to the inroads made by the independents.

A characteristic of telephone service is that it must be planned for and constructed in anticipation of future demand. A common lament of the Bell System at the time (reflected in reports to shareholders) was that its own facilities were continually inadequate to meet market demand or were not physically located where demand had developed.11 It can be conjectured that where independents did make inroads into Bell territory and literal duplication of service areas occurred, it was largely due to either the unavailability of Bell plant or the promotional efforts and attractive pricing offered by independent operating companies.

In evaluating the charge that telephone competition engendered inefficiency, poorer quality, and higher costs, several considerations must be borne in mind. All competition involves some redundancy of plant facilities and work effort. The question is whether the pressure of competing market forces produces a better or cheaper product than a single supply service. The evidence is clear that under a regime of monopoly supply, during the period I879-93, the system was stagnant. The competitive period following expiration of the Bell patents in $1893-94$ resulted in the most rapid rate of growth of service in the history of the industry as well as in a substantial reduction in rates for business and residential telephone service. This comparison alone does not satisfactorily or completely answer the question whether competition was inefficient and costly. Yet with respect to the duplication

\footnotetext{
${ }^{7}$ IgTO AT\&T ANN. REP. 23-24.

${ }^{8}$ Johnston, supra note 5 .

${ }^{9}$ In I902 the average switchboard served 225 lines. Bureau of the Census, Special ReportsTezephones and Telegraphs, table 37 , at 33 (Ig02).

${ }^{10}$ Investment per station at the turn of the century was about \$200. Igr I AT\&T ANN. REp. I7. This source shows the average plant cost per exchange station from 1895 to IgIx. The concurrent investment in station equipment is estimated at about $\$ 20$ per station.

${ }^{11}$ I900-07 AT\&T ANN. REPS.
} 
argument for inefficiency we see evidence of plant redundancy within the Bell System itself-duplication and triplication of exchange cable facilities, establishment of second and third wire centers within a few years of opening an initial office. Of course, this evidence may merely attest to the lack of omniscience of a highly centralized, carefully planned telephone organization. But just as Bell spokesmen would argue that a second cable on the pole line does not represent inefficiency or high cost, the independents could insist, during the competitive era, that in a period of extremely rapid growth (created by their existence) all facilities were efficient, necessary, and provided at reasonable cost.

The infusion of competition did force a substantial disruption of the operations of the Bell System. Profitability, rate levels and structure, and the whole innovative process were markedly affected by the coming of competition. The Bell System did not take this assault lightly. It changed tactics and practices and ultimately appealed for state intervention-the regulatory process-to stabilize and normalize competitive forces. This history is recounted below tor such light as it may shed on the relative strengths or weaknesses of competition and regulated monopoly.

II

\section{Historical Account ${ }^{12}$}

\section{A. The Period of Monopoly, I879-93}

The expiration of the basic Bell patents in $1893-94$ marked the end of the System's complete monopoly over the telephone field. Since I879 the Bell System had determined the industry's rate of expansion and the location and direction of service development as well as the charges for such service, deriving handsome profits from its efforts. At the end of 1894 , equity ownership of Bell stockholders consisted of $\$ 20$ million of common stock and \$r8 million of accumulated surplus. Of the common stock, $\$ 5$ million represented the original offering (for which $\$ 500$,oon in cash had been paid), while the remaining $\$ 15$ million came from subsequent issues. The return on this investment was almost forty-six per cent during the period, with declared dividends averaging fifteen per cent or a total of $\$ 25$ million.

Monopoly pricing had its counterpart in restricted growth. Although Bell initially contemplated the telephone for use in private line service, it soon saw the advantage of exchange service. However, high rate levels and inadequate facilities combined to prohibit rapid expansion or development. Service was provided by use of iron wire or on grounded circuits with a local battery power source ${ }^{\mathbf{1 3}}$ and was directed to customers located within a mile of the wire center. Since central offices were

\footnotetext{
12 This section is based upon the narrative in FCC, Proposed Report, Telephone Investigation pt. 2, at $134-66$ (1938) [hereinafter cited as WALKER REPORT].

${ }^{13} \mathrm{H}$. Casson, The History of the Telephone i68-69 (Igio); Bureau of the Census, Special RePORTS-TELEPHONES I4 (IgO7).
} 
usually located in the center of a large urban community's business-industrial area, residential, suburban, and rural service went largely undeveloped.

Public relations were usually ignored during the patent monopoly period while the System concentrated on reaping large profits. As later assessed by the FCC, "the System's attitude toward the public was characterized by arrogance and indifference."14

\section{B. The Competitive Period: Development of Service}

Although its patent monopoly enabled Bell to obtain franchises and establish service in the most lucrative, populous sections of the country, numerous independent telephone companies and manufacturers were formed following the expiration of these patents. While these concerns concentrated their efforts on regions not yet reached by the Bell System, they also offered competing services in many areas already served by Bell. Thus a major effect of the advent of telephone competition was the stimulation and growth of telephone service. An abbreviated summary of this development over the period $1876-1920$ is shown in Table $\mathrm{I}$.

TABLE I

Total Telephones in U.S. at December 3 I at Four-Year Intervals, I876-I920

\begin{tabular}{|c|c|c|c|}
\hline Year & $\begin{array}{c}\text { Total } \\
\text { Telephones }\end{array}$ & Year & $\begin{array}{c}\text { Total } \\
\text { Telephones }\end{array}$ \\
\hline 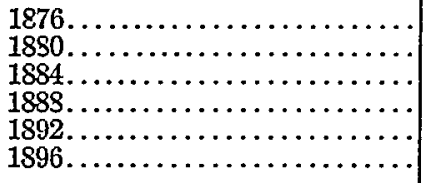 & $\begin{array}{r}2,593 \\
47,880 \\
147,715 \\
194,966 \\
260,795 \\
404,301\end{array}$ & $\begin{array}{l}1900 \ldots \ldots \ldots \ldots \ldots \ldots \ldots \ldots \\
1901 \ldots \ldots \ldots \ldots \ldots \ldots \ldots \ldots \\
1903 \ldots \ldots \ldots \ldots \ldots \ldots \ldots \\
1912 \ldots \ldots \ldots \ldots \ldots \ldots \ldots \\
1916 \ldots \ldots \ldots \ldots \ldots \ldots \ldots \\
1920 \ldots \ldots \ldots \ldots \ldots \ldots \ldots\end{array}$ & $\begin{array}{r}1,355,911 \\
3,353,247 \\
6,483,629 \\
8,951,936 \\
11,211,432 \\
13,411,379\end{array}$ \\
\hline
\end{tabular}

Source: WaLEeR REPort, table 3E, at 143-44.

Perhaps a clearer image of the effect of competition on telephone development is given by a comparison of the rate of station growth during the period of patent monopoly and in the years immediately subsequent thereto. Table 2 illustrates this effect. Seventeen years after telephone communications had originated there were 266,43 stations operating -all owned by Bell. By the end of rgo2, only ten years later, Bell maintained $x, 377,178$ stations and the independent companies owned an additional $1,053,866$. The independents were able to maintain approximately this relative position until 1907 , when they owned 3.0 million stations compared to $3 . \mathrm{I}$ million owned by Bell. ${ }^{15}$

\footnotetext{
14 WAIKER REPORT, supra note 12, at 561. A more comprehensive discussion of the Bell System's pre-I910 public relations policies can be found in N. Long, Public Relations Policies of the Bcll System, A Case Study in the Politics of Modern Industry (Ph.D. dissertation, Harvard Univ., x937).

${ }^{15}$ Bureau of the Census, Census of Electrical Industries-Telephones (1932).
} 
TABLE 2

Annual Per Cent Increase in Total Number of Telephone Stations, I885-I905

\begin{tabular}{|c|c|}
\hline Year & $\begin{array}{l}\text { Annual Fer Cent } \\
\text { Increase in Number } \\
\text { of Stations }\end{array}$ \\
\hline 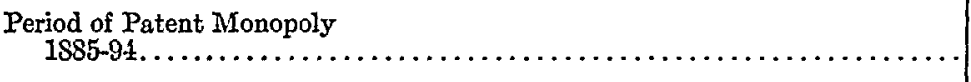 & 6.3 (avg.) \\
\hline 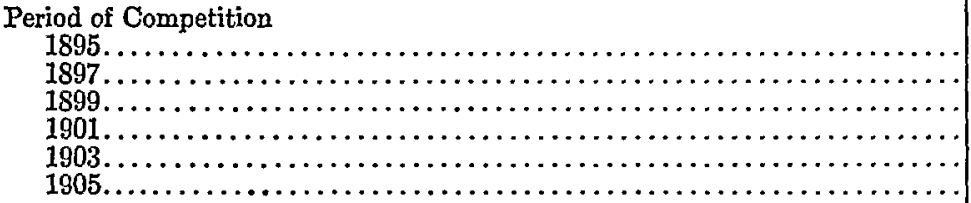 & $\begin{array}{l}19.0 \\
27.4 \\
47.6 \\
32.8 \\
18.4 \\
23.1\end{array}$ \\
\hline
\end{tabular}

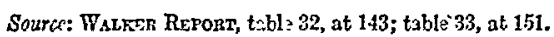

The rise of the independent companies resulted in a substantial amount of service competition during this period. Out of $x, 05 \mathrm{I}$ U.S. cities with a 1902 population greater than 4,000, $\mathrm{x}, 002$ had telephone facilities. The independents provided exclusive service in I37 of these and Bell in 4I4; the remaining 45 I communitiesalmost half-received service from two or more companies. ${ }^{16}$

The growth which characterized this early competitive era was both intensive and extensive. It was intensive in that it was marked by a higher saturation of development, particularly of residential services, than had been attempted during the period of patent monopoly. It was extensive in that service was extended for the first time to suburban and rural areas. This vigorous pursuit of new markets, engaged in by Bell as well as by the independents, was greatly facilitated by substantial rate reductions bringing the telephone within the financial grasp of a larger consumer group.

In Igo7 the Baker-Morgan banking interests gained control of the Bell System and replaced President Frederick Fish with Theodore Vail. ${ }^{17}$ Vail substantially reversed a number of Bell policies, emphasizing absorption of the competition in preference to the earlier policy of expansion of Bell-constructed facilities. This change in emphasis resulted in a rapid diminution in the independents' proportion of total industry telephones. The decline continued until the independents' share reached its present ratio of about fifteen per cent. ${ }^{18}$

\section{The Competitive Period: Rates}

As competition increased, the rates Bell had charged during the patent monopoly period decreased significantly. Average revenue per Bell station dropped from $\$ 88$

\footnotetext{
${ }^{10}$ Bureau of the Census, Special Reports--Telephones and Telegraphs (ig02).

${ }^{17}$ WaLKer RePORT, stspra note 12, at IOI-02.

${ }^{38}$ As of December 3I, I968, the Bell System had 87 million telephones, while independent companies served 17 million.
} 
TABLE 3

Comparison of Annual Exchange Rates for Bell Exchanges With and

Without CoMpetrTION, I894-I909

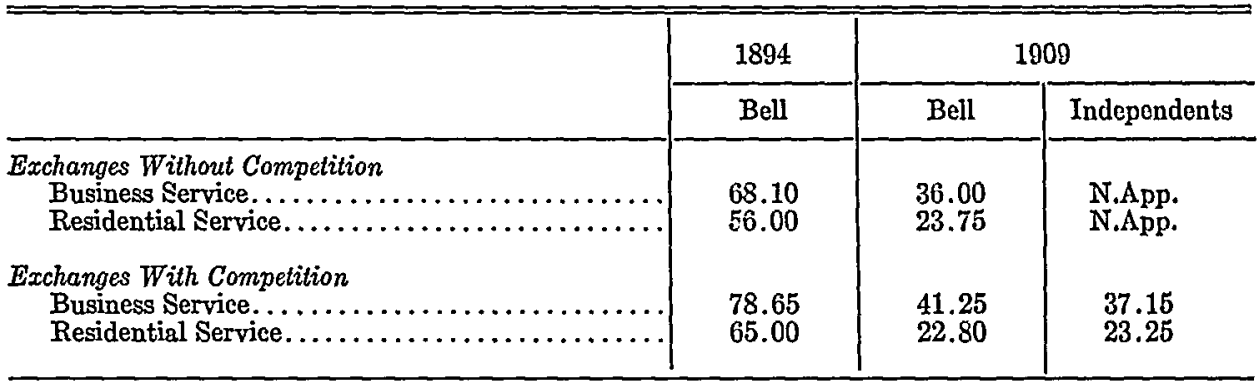

Source: 1909 AT\&T ANx. REP. 25 (chart), 28.

in 1895 , the first year of competition, to $\$ 43$ in 1907 . This effect on Bell System rates was not limited to those exchanges facing direct competition; the same benefit was also extended to patrons in areas where Bell retained exclusive service. As shown in Table 3, these rate reductions were about the same in exchange areas without competition as in those served by other exchanges in addition to Bell. President Vail used this evidence to argue that it was not the competitive forces which were leading to price reduction but cost savings initiated by the company. ${ }^{10}$ As there is no evidence of comparable performance during the period of patent monopoly, ${ }^{20}$ this turns the question slightly. Absent market competition, what incentive did the System have to generate cost economies?

\section{The Competitive Period: Development of the Art}

During the period of the Bell monopoly, the technical activities of the company were not primarily concerned with, nor organized for, development of the art through its own forces. Rather, effort was directed toward purchasing patents for the purpose of extending company control in the field of telephony. Prior to 1907 little or no attention was given by the Bell System to what came to be known as "fundamental research."21

The major developments in the art, up to this point, originated outside the Bell System. The Strowger switch, which made possible the advent of automatic telephony, was invented by an undertaker and manufactured by several of the independent manufacturers, ${ }^{22}$ while the use of dial telephone service was actually resisted by Bell leadership. ${ }^{23}$ The loading coil was developed by Professor Pupin of Columbia

\footnotetext{
${ }^{10}$ I9TO AT\&T ANN. REP. 25-29.

${ }^{20}$ WALKER REPORT, supra note 12, at 203, 243-50.

${ }^{21} I d$. at 207.

${ }^{22} \mathrm{Id}$. at 300 .

${ }^{28}$ Theodore N. Vail in 1913 AT\&T ANn. Rep. 20:

"It has frequently been asserted that the Bell System did not cmploy automatic switchboards because of patents controlled by others. ... [It] is not automatic for the subscriber as the subscriber does all the manipulation in the making of a connection."
} 
University around I905. This coil tremendously improved the quality of telephone transmission, actually making possible, for the first time, a long distance telephone system. ${ }^{24}$ Perhaps the most significant technical development of the period-and another major innovation from outside the Bell System ${ }^{25}$-was Lee De Forest's development of the vacuum tube in I9r4. There were numerous other developments of the art during this period, but they can be considered more as refinements of toll and exchange service than as major technical breakthroughs.

When Vail reassumed the presidency of AT\&T in I907, he shifted company emphasis from patent purchase and development to the creation of a technical and research staff capable of "occupying the field":

One of the first things that was fully developed in our minds was the necessity of occupying the field; ... . Just as soon as we started into the district exchange system we found out that it would develop a thousand and one little patents and inventions with which to do the business which was necessary, and that is what we wanted to control and get possession of. So from the very commencement we had our experimental department, so-called . . . whose business it was to study the patents, study the development and study these devices that either were originated by our own people or came in to us from the outside. ${ }^{26}$

The objective of dominating the field and asserting technical leadership in the telephonic and allied arts has served the company well down to the present day. In I927 J. E. Otterson of the company restated and amplified the Bell System objective in the following words:

A primary purpose of the American Telephone \& Telegraph Co. is the defense and maintenance of its position in the telephone field in the United States. Undertakings and policies must be made to conform to the accomplishment of this purpose.

The American Telephone \& Telegraph Co. is surrounded by potentially competitive interests which may in some manner or degree intrude upon the telephone field.

The problem is to prevent this intrusion.

....

... [T] he best defense is to continue [research] activities in "no man's land" and to maintain such strong engineering, patent, and commercial situation in connection with these competitive activities as to always have something to trade against the accomplishment of other parties. ${ }^{27}$

Although it is surrounded by other industrial fields such as satellite communications and the computer application to switching and information storage, the Bell System

\footnotetext{
${ }^{26}$ Doherty, The Bell System and the People Who Built It, 46 BeLI LAB. RECoRD 76-83 (I968).

${ }^{25}$ Id. at 38-46; WALKER REPORT, supra note I2, at 4 I5.

${ }^{20}$ Testimony of Theodore N. Vail, Record, vol. 2, at $\mathrm{x} 542-43$, Western Union Tel. Co. v. American Bell Tel. Co., I87 Fed. 425 (I9II), reprinted in WALKER REPORT, supra note I2, at 203 n.7.

${ }^{27}$ Memorandum by J.E. Otterson, Jan. 13 , 1927, reprinted in WalkER REPORT, supra note I2, at 23536.
} 
now enjoys a controlling position in the field of wire telephony. The strong financial and technical resources of the Bell System, and particularly the research policy initiated by Theodore Vail, underlie its defense against any threatened invasion.

\section{E. Airing the Dispute Over Competition}

Despite the greater availability and reduced rates for telephone service, there was public criticism, particularly from the business community, of the duplicate service situations. Much of this criticism was stimulated by the Bell System, but the independents were not loath to build their own "back-fires." Theodore Vail's first annual report to stockholders, which was reproduced and widely distributed to press and public organs, treated the theme of telephone competition at length:

Duplication of plant is a waste to the investor. Duplication of charges is a waste to the user....

... [T] he public must pay double charges, on double capital, double operating expenses and double maintenance. ${ }^{28}$

In two widely disseminated reports, the independents prepared a response to President Vail. They are quoted at some length to obtain the flavor of the controversy:

Previous to 1895 , when independent telephony began, it was next to impossible for a small town to get even a toll station established.... The style and efficiency of the transmitter was the same practically throughout the monopoly and the circuit conditions had undergone little or no change, the lines being mostly grounded circuits of iron wire .... Operators' service was given very little attention .... [T] hey failed to properly appreciate conditions peculiar to varying localities ....

... [P]robably the strongest ground for complaint was exorbitant rates. ...

The very first effect of competition was a bettering of the service rendered by the Bell Company by more careful attention to operators' work, the substitution of either common return or metallic circuits for grounded lines, and, the introduction of different grades of service (party lines) by which means they offered cheaper rates with the minimum of reduction in revenue per line to themselves. . . After these came quickly, the extension of toll lines to small places, and a marked difference in their interest in local conditions. ${ }^{29}$

[Columbus, Ohio, is cited as an illustration of the beneficial effects of competition.] The Citizens Telephone Company [independent] began agitation for a franchise late in 1898, when the Central Union (Bell) Telephone Company had less than 1900 telephones, with rates near the business district as high as $\$ 96$ a year for business telephones and $\$ 48$ for residence telephones, and with additional charges for distance beyond one mile or more from the exchange. The rates throughout the city today [Ig08] are respectively $\$ 54$ and $\$ 27$ a year for Bell main line business and residence telephones. ... At the present time each company has in the neighberhood of 12,000 [telephones] ....

${ }^{28}$ rg07 AT\&T ANN. REP. I8.

${ }^{20} \mathrm{~J}$. Ainsworth \& G. Johnston, A Discussion of Telephone Competition 7-8 (Int'l Independent Tel. Ass'n, Feb. 1908). 
[The author goes on to discuss the accessibility of 24,000 stations for about the same total charges as for rgoo stations ten years previously.]

... [Duplicate investments] are mostly in the business districts nearest the exchange, where the cable units, by reason of short lengths and the most economical sizes, are cheapest ....

Switchboards, if not connected, are cheaper separated than combined. . . .

Two pole lines may represent waste when they are parallel with no more of a load than could be borne on one. They may have no element of waste with a greater load, or when shared with other wire-using companies. ...

Of the subway and conduit system only that smaller portion is waste which is represented by the costs of opening and repaving the streets ....

The cost of interior wiring and instruments is duplicated only in proportion to the duplication of telephones. ${ }^{30}$

The public airing of this controversy over the relative benefits and disadvantages of telephone competition may have had some effect on the informed public. But as in many industrial battles over markets, the most effective weapons were financial and economic. To understand this result, we must examine the Bell System response to competition.

\section{III}

\section{Bell Reaction to Competitron ${ }^{31}$}

The loss of its patent monopoly in 1893 and the incursion of competition was followed by the Bell System with efforts to destroy or mitigate the effects of the competition. Tactics employed for this purpose during the tenure of President Fish differed markedly from those initiated by President Vail in 1907. In the early period competition was met through rapid expansion of Bell service. In the later period, rg07-20, when the Baker-Morgan financial interests had obtained control of the company, competition was allayed by purchase and absorption of independent properties. In addition to a change in method of expansion, Bell employed other devices which are discussed below in the comparison of the two eras. The change in the Bell System's rate of expansion of telephone service is shown in Table 4.

\section{A. Early Competitive Era, I894-rgo6}

During the period r894-rgo6 the Bell System employed a variety of methods in addition to its expansion policy in meeting the independents. Among these were (I) an active propaganda campaign; (2) refusal to connect with certain independent companies; and (3) refusual to sell telephone instruments to non-Bell companies.

\section{Bell Reprisal: Propaganda Campaign}

Bell's propaganda against the independents took many forms. Its objective was to undermine the competition's interests with the public, with bankers, with legis-

\footnotetext{
${ }^{30}$ Johnston, supra note 5, at 6-8, 15-16.

${ }^{31}$ This section is based upon the narrative in WALKER REPoRT, supra note 12, at 134-66.
} 
TABLE $_{4}$

Annual Rate of Growth in Bell Telephone Stations and Plant Investment, I885-I9I2

\begin{tabular}{|c|c|c|}
\hline Period & $\begin{array}{l}\text { Average Per Cent } \\
\text { Increase in Number } \\
\text { of Telephone } \\
\text { Stations }\end{array}$ & $\begin{array}{l}\text { Average Per Cent } \\
\text { Increase in Plant } \\
\text { Investment }\end{array}$ \\
\hline 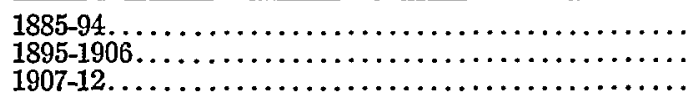 & $\begin{array}{r}6.3 \\
21.5 \\
9.6\end{array}$ & $\begin{array}{r}8.2 \\
15.0 \\
8.5\end{array}$ \\
\hline
\end{tabular}

Source: WaLKER REPOnT, tables 33 \& 34, at 151, 152.

latures, and with present or prospective investors. This campaign appears to have had considerable success against the larger independent telephone companies. However, the smaller mutuals and independents, which grew directly out of local community needs and were less dependent on central capital markets, were apparently less affected by the propaganda efforts.

\section{Bell Reprisal: Refusal of Interconnection}

Refusal to connect with independent telephone systems for long distance telephone service afforded Bell a stronger means of curbing the independent movement. Since Bell was the pioneer in this field, its refusal to connect confined independent companies within the limits of the particular territories they served. The independents early recognized this weakness of their position, and they attempted, in I899, to form an independent long-distance network. The extensive financing required for such an undertaking was to be organized through a consortium including the Peter Widener interest. At the request of Mr. Morgan of the banking firm, Widener withdrew as financial sponsor of the undertaking, and it collapsed shortly thereafter.$^{32}$ It it significant that the Baker-Morgan group shortly thereafter acquired the Bell properties and made them the nucleus of an even stronger communications system including both the Bell System and Western Union Telegraph Co. ${ }^{33}$

\section{Bell Reprisal: Refusal to Sell}

Another weapon employed by Bell against the independents was its refusal to sell telephone equipment outside the System. This encouraged the development and growth of independent telephone manufacturing concerns once the Bell patents had expired, and the three most important independent manufacturers-Kellogg Switchboard \& Supply Co., Stromberg-Carlson Telephone Manufacturing Co., and Automatic Electric $\mathrm{Co}^{34}$-were established during this period. The existence of the in-

\footnotetext{
${ }^{32} 69$ Com. \& Fin. Chronicle II5I (I 899).

${ }^{33}$ WALKER REPORT, supra note I2, at 99 n.I4.

${ }^{34}$ It is interesting to note that today these three companies are subsidiaries of ITT, General Dynamics, and General Telephone, respectively.
} 
dependent telephone manufacturing firms encouraged competitive product development. Development of automatic dial service, the supplanting of local magneto by common battery service, development of full manual multiple-operator service, and a number of refinements in relay manufacture can be traced to the efforts of independents during this period. ${ }^{35}$ Independent innovations in harmonic ringing and signalling systems eventually led to problems of system compatibility when Bell later partially reversed its position and sought interconnection with the independents.

The refusal of the Bell System to sell telephone apparatus to independents failed to stop their competition, so Bell then attempted to acquire control of Kellogg and Stromberg-Carlson. Both attempts ultimately failed through intervention of public authorities, who had them set aside on the ground that they would create a monopoly in the manufacture of telephone equipment.

\section{B. Late Competitive Era, I907-20}

The onset of Baker-Morgan control over the System in 1907 precipitated an abrupt change in Bell's policy toward independents. This reversal was evidenced by a reduction in the rate of Bell System internal expansion coupled with a policy of buying up independent properties. As Table 4 indicates, the average rate of growth of Bell stations in the early period of competition, I895-Ig06, was 2I.5 per cent; while for the years $\mathrm{x} 907$-I2 the annual rate of expansion dropped to 9.6 per cent.

Rapid market expansion had cost heavily in investment dollars, and rate levels were declining so fast that revenue increases lagged investment growth. In successive reports to stockholders, President Fish lamented the decreasing profitability resulting from competition:

[I]n certain localities, rates too low to cover current expenses and necessary allowance for renewal have been offered, to meet similar rates offered by competitors. ${ }^{36}$

And again in 1904:

In some places in the country, particularly where there has been the demoralizing effect of unintelligent competition, the rates are at the present time too low. ${ }^{37}$

In his last annual report, President Fish repeated the theme:

[T] The unintelligent views of our competitors as to what rates for service are possible have created conditions in the portions of the country to which reference is now made, under which neither they nor the Bell companies are getting proper returns for the service rendered. ${ }^{38}$

President Fish's critical remarks about the "unintelligent competition" were stimulated by real events. During the period of patent monopoly, the company had

\footnotetext{
${ }^{35}$ T. Garx, The Story of the Independent Telephone Industry (circa I935).

${ }^{30}$ rgoo AT\&T ANN. Rep. Io.

${ }^{37}$ I904 AT\&T ANN. REP. IO.

${ }^{38}$ I906 AT\&T ANN. ReP. 12.
} 
enjoyed an average return on investment of nearly forty-six per cent. For the competitive years I900-06, net earnings on average net investment dropped to the vicinity of eight per cent. ${ }^{39}$

To meet the competition, as noted above, President Fish had initiated a program of rapid plant expansion. Between 1895 and I905, Bell System assets nearly quadrupled, rising from $\$ 120$ million to $\$ 453$ million. ${ }^{40}$ The need for what, at that time, were tremendous additional capital resources, led to control of the System by the Baker-Morgan financial interests and the replacement of Fish by Vail. ${ }^{41}$ President Vail, in addition to slowing the rate of company expansion, introduced other major policy changes which effectively challenged the competition's advance. These policies were quite different from those of the early competitive era and are discussed under (I) policy of acquisition; (2) interconnection; (3) sales to independents; and (4) regulation.

\section{Late Competitive Era: Acquisition Policy}

With the curtailment of its own rate of internal expansion, the Bell System, beginning in 1907 , launched an aggressive program of acquiring independent telephone properties. The effect of this change in policy is demonstrated by the shift in the ratio of telephones between the two segments of the industry. In Ig07 the independents owned 3.0 million stations, while Bell owned 3.I million. By I9r2, there were 3.6 million independent stations and 5.x million Bell stations. ${ }^{42}$ The proportion of independently owned stations decreased progressively until about I940.

Bell's acquisition attempts were strongly resisted by the independents, who made complaint to the Attorney General, George Wickersham. They were joined in charging antitrust violations by the Postal Telegraph-Mackay interests, because the Bell System had earlier succeeded in acquiring control of Western Union Telegraph Company, and the physical consolidation of Bell System and Western Union properties threatened to undercut Postal Telegraph markets. ${ }^{43}$

As a result of these complaints, AT\&T vice-president N. C. Kingsbury met with the Attorney General and later in I9I3 drafted an agreement which became known as the Kingsbury Commitment. ${ }^{44}$ Under this agreement, the Bell System agreed not to acquire control over any competing company, and it agreed to connect its system with those owned by independents if the latter met Bell System equipment requirements. The Commitment did not restrict the Bell System from acquiring

\footnotetext{
${ }^{39}$ Staff Reports, Exhibit ${ }^{3} 360-B$, table 84 , at 425 , prepared for introduction into evidence for the WALKER REPORT, supra note 12.

${ }^{40} I d$., Exhibit 1360-A, table 7, at 52.

\$1 See text accompanying note 17 supra.

12 I932 Census, supra note 15.

${ }^{13}$ Staff Reports, supra note 39 , Exhibit $2096-\mathrm{D}$, ch. 3. It is interesting to note that the Bcll System's first attempt to unite the telephone and telegraph industries involved the Mackay-Postal Telegraph interests in preference to Western Union. WALKER REPORT, supra note 12, at 97-99.

"The Kingsbury Commitment is reproduced in I9ז3 AT\&T ANN. REP. 24-26.
} 
noncompeting telephone companies. Between I9I3 and rgI7 the Bell System purchased over 241,000 stations from the independents and sold 58,000 stations. During the war years, I9r8-19, the Post Office Department assumed control over all telephone properties, and these were the only years after Igr2 when the Bell System sold more stations than it acquired.

The competitive milieu created by the Kingsbury Commitment was not viable for many independents, as they were unable to dispose of their properties on favorable terms. Therefore, the independents joined Bell in seeking passage of the WillisGraham Act of rg2r, which permitted the merger or consolidation of competing telephone companies. ${ }^{45}$ Passage of the Willis-Graham Act was construed by the Attorney General as terminating the Kingsbury Commitment, and Bell again undertook an aggressive policy of acquiring independent properties. The intensity of Bell's activity in this regard once again created apprehension among the independents. After some negotiations, the Bell System sent a letter, which became known as the Hall Memorandum, to F. B. MacKinnon, president of the United States Independent Telephone Association. Dated June 14, I922, this correspondence stated Bell's new policy relative to acquisitions. The Bell System agreed "to make no purchases of, or consolidations with, independents unless demanded for the convenience of the public or unless special reasons existed making the transaction desirable for the protection of the general public service or Bell System property." ${ }^{\text {"6 }}$ Using these two exceptions the Bell System then continued to make such acquisitions of independent properties as it desired.

\section{Late Competitive Era: Interconnection}

Until the Kingsbury Commitment was entered into in rgr3, the Bell System, in varying degrees, refused to interconnect with independent exchanges for longdistance service. President Vail explained the Bell System hostility to interconnection: "Offering a connection with a so-called competing exchange . . . is offering a different service, except so far as they connect the same subscribers, and there it is of no benefit, as either one would serve the purpose." ${ }^{.47}$

The independent telephone companies resisted interconnection as well and were active in opposing state legislation which would compel physical ties between competing telephone companies. This viewpoint was expressed by F. B. Mac-

\footnotetext{
${ }^{\Delta 5}$ Act of June Io, I92I, ch. 20, 42 Stat. 27. The legislative history of the Willis-Graham Act is in the ICC official library. 6I Cong. Rec. I983 (I92I) (remarks of Representative Winslow):

"The bill was brought to the attention of the committee by those representing a very large majority of the so-called independent telephone companies of the United States.

". . Many of them ... are skating on very thin ice in respect of their financial operations. ... [T] hey have represented to the committee ... that if the opportunity to sell or consolidate is not afforded to them they are liable to go through the condition of bankruptcy . . .." ${ }^{\circ}$ WALkER REPORT, supra note 12, at 158 .

47 Ig09 AT\&T ANN. Rep. 24.
} 
Kinnon, president of the United States Independent Telephone Association, before a joint congressional committee as follows:

Representative Huddesston. How does it [compulsory interconnection] ruin an exchange?

Mr. MacKinnon. If an exchange which is now operating successfully is obliged to give up its entire toll system and its connections to another exchange in the same town and which has no money invested in that toll system, it may be that that other exchange ... can take away the subscribers of the other exchange. ${ }^{48}$

The successful competitor strives to become the surviving monopolist.

It is futile to reflect on what could have been. In view of the opposition by both segments of the telephone industry to interconnection of competing facilities and the general laissez-faire attitude of public authorities, the likelihood of achieving interconnection was remote. Despite the independents' inadequate financial resources (partly due to Bell pressure), had there been full interconnection during the early years of competitive rivalry, it may be hazarded that the structure of the telephone industry would have been more equally balanced. There is little question but that interconnection would have relieved subscribers of the burden of dual instruments and separate directories and lessened the public demand for forced consolidations. The Bell System watchword "Universal Service" could have been achieved without "One System, One Policy."

It may be that the extensive financial resources of the Bell System, with its banker support, would, in any event, have overwhelmed the struggling independent industry. The independents were fragmented and frequently fought as bitterly among themselves as they did against the Bell System. By the time Vail assented to interconnection with noncompeting independents, the relative decline of this segment of the industry was evident. It was a decline brought on by Bell's aggressive acquisition policy and the financial difficulties being experienced by the independents. In part, the inability of independents to secure additional capital is explained by the reluctance of bankers to finance closed systems-exchange areas without access to the outside world through toll interties. During the critical years in which the legislators might have acted, 1893-1907, the public and the companies were disinterested. Policy, in an issue of this sort, is made through the clash of competing interests. Because both segments of the industry opposed interconnection at the time, a salient opportunity was lost.

\section{Late Competitive Era: Bell Sales Policy}

As noted earlier, the refusal of the Bell System to sell telephonic equipment to non-Bell companies proved a failure as a weapon in fighting the independents. With the advent of banker control of the Bell System in 1907, this policy was

\footnotetext{
${ }^{43}$ Joint Hearings on S. 1313 Before the Committees on Interstate Commerce, 67th Cong., Ist Sess. 8 (I921).
} 
reversed, and sales to independents and on the open market were permitted. There were several reasons for changing the company sales policy toward independents. At the time (1907), the Bell System patent situation was such that the company had almost no exclusive patent protection which would prevent independents from developing satisfactory central office, outside plant, or station equipment. The vigorous development of independent telephone manufacturers, concurrent with the growth of independent telephone operating companies, attested to this fact. By rgo7 there were about as many independently owned telephone stations as Bellowned stations. The independents constituted a sizeable prospective market for Western Electric, Bell's wholly-owned manufacturing subsidiary, and Western sought a share in this independent market in competition with the independent manufacturing firms.

In addition, there were future advantages in undertaking the sale of BellWestern equipment to the independent operating companies. Vail had initiated a deliberate policy of acquiring independent operating properties and absorbing these into the Bell System. The installation of Bell System equipment into independent plant made for compatibility and uniformity of equipment and rendered later acquisition of such companies more attractive. ${ }^{49}$

\section{Late Competitive Era: Regulation}

Possibly the most significant policy reversal initiated under Vail's tenure as AT\&T president was with respect to public regulation. Throughout the period of patent monopoly ( $1873-93$ ) and the early years of competition (I894-1906) the Bell System opposed government intervention and regulation of the telephone business. This view was wholly consonant with the prevailing industrialist viewpoint. Bankers, however, require more stability and rationality of operations than can be evinced by a cutthroat competitive environment. President Fish was ousted and Vail reinstated as president of the Bell System by the Baker-Morgan banking groups. These large eastern banks had been key witnesses to the creation and operation of the Interstate Commerce Commission and had observed federal regulatory efforts to reduce the rail carrier intransigency which produced "price wars." The ICC was "making good" in its efforts to stabilize markets and price structures in the railroad business without invading private managerial prerogatives. Vail early saw the possibilities of effecting such normalization and stability in the telephone industry.

The opening signal of this reversal of viewpoint was the discussion of "Public Control" in the rg07 Annual Report to stockholders:

It is contended that if there is to be no competition, there should be public control.

It is not believed that there is any serious objection to such control, provided it is independent, intelligent, considerate, thorough and just, recognizing, as does

\footnotetext{
${ }^{\circ}$ This thesis is developed further in Staff Reports, supra note 39, Exhibit 2096-D.
} 
the Interstate Commerce Commission in its report recently issued, that capital is entitled to its fair return, and good management or enterprise to its reward.50

Two years later Mr. Vail was somewhat more equivocal:

Although there have been abuses in corporate management . . . yet it must be admitted that the tremendous development of utilities in this country as compared with other countries ... is to a certain extent due to the lack of proscriptive restrictions.

We believe that if there is to be control, there should be protection .... We believe that management or operation by a body without any accountable responsibility [i.e., regulatory commissions] would be prejudicial to the best interests of the service and of the public, and destructive . ...51

By rgro President Bell could see the broad picture:

It is not believed that this [integration of service] can be accomplished by separately controlled or distinct systems nor that there can be competition in the accepted sense of competition.

It is believed that all this can be accomplished to the reasonable satisfaction of the public with its acquiescence, under such control and regulation as will afford the public much better service at less cost than any competition or governmentowned monopoly could permanently afford ....

... [T] [Tis "supervision" should stop at "control" and "regulation" and not "manage," "operate" nor dictate what the management or operation should be ... .

If there is to be state control and regulation, there should also be state protection-protection to a corporation striving to serve the whole community . . . from aggressive competition which covers only that part which is profitable.

A public utility giving good service at fair rates should not be subject to competition at unfair rates. ${ }^{52}$

Regulation is a two-sided coin: on one side lies the aspect of public protectionprofit limitations, the obligation to provide service at nondiscriminatory rates, and so forth. The other side of the coin bears the aspect of utility protection-including bars to ccmpetitive entry, exclusive franchise, and the right of eminent domain. With an insight that was to serve Bell corporate interests well, Vail anticipated the limited inroads that public regulation would make in obtaining the first series of objectives and the extensive benefits conferred by the second. 'Real power would always rest with those responsible for management of telephone operations, and Vail was always insistent on the distinction between "regulation" and "management." Although the program of acquiring independent properties was being pursued unabated, the

\footnotetext{
${ }^{50}$ I907 AT\&T ANN. REP. I8.

51 Ig09 AT\&T ANN. REP. 34, 36.

52 I9YO AT\&T ANN. REP. 23, 32, 33.
} 
combined objective of "Universal Service-One System, One Policy" could not be achieved without political intervention. Bell's response to this limitation was the promotion of regulatory authority in utility commissions.

The Bell System objective of substituting regulation for the rigors of market competition was met. In Igro Congress enacted the Mann-Elkins amendment to the Interstate Commerce Commission Act, a portion of which conferred regulatory authority over interstate telephone companies on the ICC. ${ }^{53}$ Between Igro and 1920 thirty-one states established authority for regulating intrastate operations of telephone companies. ${ }^{54}$

The history of the federal enactment is peculiar in that the original legislative proposal was intended solely to confer appellate jurisdiction over ICC decisions concerning railroad matters on a Commerce Court. In twenty-six parts of the hearings before the House Interstate and Foreign Commerce Committee, there is no testimony or mention of the communications industry. ${ }^{55}$ The original bill, as reviewed by the committee, was amended on the floor of the House to confer authority on the ICC over "telephone, telegraph and cable companies." Bell System with regard to this legislation were made informally. The position of the independent industry was also favorable, as reflected in a letter from J. B. Ware, Secretary of the National Independent Telephone Association, to Senator W. Alden Smith of Michigan. ${ }^{57}$

It is not unlikely that the Bell System shared the view of Samuel Insull, Chicago utility executive, when he told the National Civic Federation that he preferred to "help shape the right kind of regulation than to have the wrong kind forced upon [him]." W8 With clear-minded dedication, the Bell System did "help shape the right kind of regulation." During these years it furnished legislative consultants to "help and advise" state and federal legislators and to maintain continuing liaison with regulatory commissioners and their staffs.

In the twenty-four years (Igro-34) that the ICC regulated telephone companies, the Commission dealt with telephone rates in only four cases, none of which involved issues of major importance. "The Commission undertook no general rate investigations; it acted only on the basis of such complaints as were brought before it. ...

\footnotetext{
${ }^{63}$ Act of June 18, x 9 10, ch. $309, \S 7,36$ Stat. 544 .

"H.R. ReP. No. I09, 67th Cong., Ist Sess. 3-4 (I92I).

to Hearings on Bills Affecting Interstate Commerce Before the House Comm. on Interstate and Foreign Commerce, 6rst Cong., 2d Sess. (Igro).

50 The legislative history of the Mann-Elkins Act is filed in the ICC reference room.

${ }^{67}$ Letter from J.B. Ware to Senator W. Alden Smith, May 20, I910, 45 CoNg. Rec. 6973-74 (I9I0): "[T]he Bell interests have in spots furnished service at less than cost, and in many instances without cost for months, and ... years . . . .

"We do not ask the Government to fight our battles, but we do ask for protection against outrageous methods of warfare which are illegal and detrimental to the public welfare. . . We are not afraid of supervision; we believe in regulation ....."

${ }^{68}$ Letter from Ralph M. Easley to George W. Perkins, June 9, I909, in J. Weinstein, The Corporate IdeAL in the Liberal State: Ig00-IgI8 at 87 (I968).
} 
In the absence of serious pressure to exert its power in the communications field, regulation went largely by default.."59

We have the vision of hindsight. President Vail, after four years of operating under the law, enlarged upon his regulatory experience in addressing his shareholders:

Regulation and control by commissions or business courts have . . . become a permanent feature of our economic laws. ... The few years' experience has brought out prominently both good and bad features, but it has demonstrated ... a satisfactory solution of the economic problems ....

Business courts . . . will soon bring order and security out of the present uncertainty and be a bulwark against future economic disturbance.

... [T] The Bell System has no cause for complaint, protest or criticism as to its relations with ... commissions .... [R]ight and reason have been the controlling influences in the conclusions reached. ${ }^{.0}$

\section{IV}

\section{ConcLuston}

In a sense all business enterprise is a flight from competition. The penalties of competition-low or nonexistent profits-may be avoided by superior efficiency, by product innovation or differentiation, or by attenuation of the competitive process through control over supply and price wielded monopolistically or through conspiracy or tacit understanding with competitors. Confronted by the vigorous competitive inroads of independent operating companies, the Bell System sought to escape the unaccustomed hardships of competition by acquiring competitors, by limiting their markets and their services, and by espousing the development of governmental regulatory functions. The public service commissions, which ultimately stabilized rates and earnings, adopted the norms of business policy urged by the System and imposed strictures on the "unintelligent competition." The advantages thus gained by the Bell System over its remaining competition have been parlayed into a practically unassailable market position fortified by political and legal ramparts.

The thesis has been posed that telephone competition during the years $1893^{-}$ 1920 was neither inefficient nor costly but was, on the contrary, productive of benefits sharply outweighing its costs. It was not just the working out of the competitive market process toward the emergence of inevitable "natural" monopoly which destroyed the structure that permitted competition to flourish and its benefits to be enjoyed; it was as much a poorly conceived, Bell-inspired, protectionist regu-

\footnotetext{
${ }^{50}$ M. Fainsod, L. Gordon, \& J. Palamountain, Government and the american Economy 375 (3d ed. 1959).

${ }^{\text {go }}$ I9I $_{4}$ AT\&T ANN. ReP. 47-49.
} 
latory policy which failed to preserve such competition as might usefully have served the public interest. This history is irreversible in that private telephone monopoly is established and institutionalized. In the absence of advocates for countervailing interests, the viewpoint of private monopoly has melded with and been espoused by public regulatory authority. The contemporary rationale for communications monopoly has not moved far ahead of Theodore Vail; the words are different, but results and objectives remain the same. In the name of "systemic integrity," "economies of scale," and "unitary planning," arguments have been made for extending the present market and regulatory structure. ${ }^{61}$ Yet over the long run, dynamic technology may provide more effective control over communication rates and services than unaided regulation can supply. After years of experience, regulation remains unproved, but the gratifying performance of the competitive marketplace from I893 to I920 has been forgotten. Perhaps, if nothing else, the public presumption that regulation is necessarily inspired and informed by the public interest can be re-evaluated in the light of the history recalled above.

Revolutionary shifts in technology and aggressive innovation will be aborted if they do not receive the support of thoughtful public policy. The Presidential Task Force on Communications Policy has suggested that domestic communications satellite service be treated as a regulated monopoly. ${ }^{62}$ The Task Force maintains that spectrum shortage and the limited number of orbital "parking slots" necessitate a single, multiple-purpose satellite system. But any policy must operate within existing technical constraints; policy making only begins at this stage. We must also consider what organizational forms will permit the greatest development of the art, the widest play of operating alternatives, and the most deliberate impetus to novel and experimental application of satellite technology. In a sense we are again at the same threshold that policy makers confronted in I893 with the opening up of a new industry. Today, as then, policy decisions on market structure and the respective roles of competition and regulation, once made, cannot be easily reversed.

\footnotetext{
01 TASK FoRCE REPORT, stipra note 4, ch. 6.

${ }^{09} \mathrm{Id}$. ch. 5. This proposal has not been favorably received by Bell System spokesmen. See Ashley, International Communications: What Shape to Come?, in this symposium, p. $4 \mathrm{I} 7$.
} 